\title{
Challenges Faced in Managing Covid-19 Pandemic Case Study: Malaysia
}

\author{
Noor Yasmin Zainun ${ }^{1 *}$, Nadiatul Nazleen Ajman², Noralfishah Sulaiman ${ }^{2}$, Shabir \\ Hussain Khahro ${ }^{3}$
}

\author{
${ }^{1}$ Jamilus Research Center (JRC), Faculty of Civil Engineering and Built Environment Universiti Tun Hussein Onn \\ Malaysia (UTHM)86400 Parit Raja, Batu Pahat, Johor \\ ${ }^{2}$ Faculty of Technology Management and Business Universiti Tun Hussein Onn Malaysia (UTHM) 86400 Parit Raja, \\ Batu Pahat, Johor \\ ${ }^{3}$ Department of Engineering Management Prince Sultan University 11586, Riyadh, Saudi Arabia \\ *Corresponding author. Email: nryasmin@uthm.edu.my
}

\begin{abstract}
The World Health Organization (WHO) characterized COVID-19 as a pandemic, pointing to over 3 million cases and 207,973 deaths in 213 countries and territories on 11th March 2020. The COVID-19 pandemic is a catastrophic occurrence that has not been seen since the Spanish Flu. The infection has not only become a public health crisis but also affected the global economy. The objective of this paper is to determine the challenges faced in managing COVID-19 pandemic in Malaysia. In this research, the secondary data was used by reviewing through the articles and journals. Content analysis was made and the outcomes of this research have successfully emerged. As a result, the most significant challenges identified in managing COVID-19 pandemic in Malaysia are Financial Resources, Health Care System, Social Challenges, Education System, and Threats to Mental Health.
\end{abstract}

Keywords: Covid-19, Health Care System, Secondary data

\section{INTRODUCTION}

COVID-19 is a global pandemic of Coronavirus Disease (COVID19) in 2019, caused by Severe Acute Respiratory Syndrome Coronavirus 2 (SARSCoV2). On December 31, 2019, the World Health Organization (WHO) received a cluster case report of unexplained viral pneumonia in Wuhan, Hubei, and launched an investigation in early January. According to "Public Health Emergencies of International Concern (2020)", the World Health Organization announced an outbreak on January 30, 2020, and announced a pandemic on March 11,2020 . The new coronavirus SARSCoV2 was first discovered in Wuhan in December 2019. Chinese cities. Hubei Province, with a population of 11 million, after an outbreak of unexplained pneumonia.

Neurosurgery [1] mentioned that the coronavirus were confirmed to have arrived in Malaysia in January 2020. The virus was found in travellers arriving from China via Singapore on January 25 after the outbreak of
COVID19 in Hubei, China. The largest group is related to the Tablighi Jamaat religious gathering held in Sri Petaling in late February and early March, which led to a surge in local cases and the export of cases to neighbouring countries. Within a few weeks, Malaysia recorded the highest cumulative number of confirmed COVID19 infections in Southeast Asia, from less than 30 cases at the beginning of this month ([2], surpassing the 2,000 active cases mark at the end of March.

As of $20^{\text {th }}$ April 2020, Malaysia has recorded more than 5,300 positive cases, including 89 deaths. Most of these cases can be traced back to religious gatherings, which have now reached the fifth generation of infection [3]. Vlaanderen [4] stated that on March 16, 2020, Malaysian Prime Minister Tan Sri Muhyiddin delivered a televised speech and announced Malaysia's Movement Control Order (MCO) as a preventive measure in response to the COVID19 pandemic in the country. Similar to the locks in China and Italy, the MCO restricts most 
non-essential activities outside the home. Malaysians are only allowed to leave home for basic activities, such as buying basic needs and medical treatment, and the MCO also restricts the entry and exit of foreigners to Malaysians [5].

The WHO recommends that the incubation period of COVID19 infection is within 14 days and may spread during this period. The spread of SARSCoV2 easily occurs through respiratory droplets, direct and indirect contact with the mucous membranes of the eyes, mouth and nose [6]. The main manifestations of patients infected with COVID19 at the time of onset are fever, cough, dyspnea, myalgia, and fatigue. Other symptoms reported by patients include headache and diarrhea [7].

In Malaysia, when neighbouring Singapore reported the first case of COVID-19 imported from Wuhan, China on January 23, 2020, the threat of COVID-19 was highlighted, which was also the first case in the Republic [6]. Eight close contacts were identified linked from the first case and located in Johor, Malaysia. More than $35 \%$ of the COVID cases in Malaysia are directly related to the mass gathering in Sri Petaling from $27^{\text {th }}$ February 2020 to $1^{\text {st }}$ March 2020 [8]. The Sri Petaling Rally is a Muslim missionary movement, with more than 19,000 people participating in Tabligh, with 1,500 followers from India, South Korea, Brunei, China, Japan and Thailand.

Malaysia probably could have another spike of COVID-19 infection in third wave due to uncooperative patients who did not disclose their travels histories and flouting quarantine conditions, which put a higher infection to the front liners and healthcare workers as well [9]. The third wave of COVID-19 infections could also be caused by the number of Malaysian's students and workers returning from overseas and also among people who had travelled before the lockdown came into force on March 18 [10]. Following to the COVID-19 cases have been rising sharply, the government Malaysia has been decided to implement lockdown via Movement Control Order (MCO) nationwide, beginning from $18^{\text {th }}$ March 2020 [11].

The 2020 MCO is called a partial lockdown, marking an important step taken by the Malaysian government to flatten the curve of the COVID19 pandemic. The official media played an important role in providing the latest news from the $\mathrm{MCO}$, and urged everyone across the country to stay home during the MCO's term, minimize unnecessary travel, pay attention to hygiene and maintain social distancing [12].

The challenges during the pandemic will be to deal with the main consequence of the economic recession and it caused and its impact on the mental health of chil- dren and their families [13]. According to the United Nation's Educational, Scientific, and Cultural Organization (UNESCO), the pandemic has disrupted the learning of more than 1 billion students in 129 countries around the world [14]. The challenges facing the health system include a serious shortage of qualified human capital in healthcare, which cannot meet the health needs of current and emerging populations around the world that the World Health Organization has identified [15].

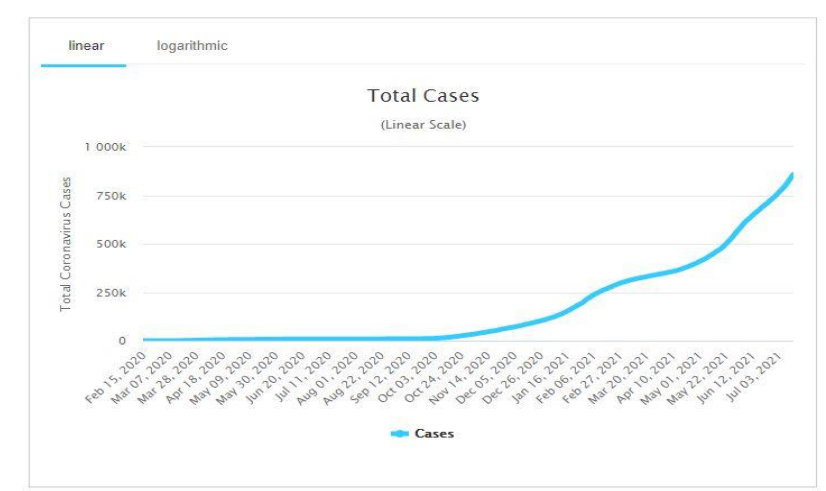

Figure 1. Total Coronavirus Cases in Malaysia. [16]

Based on the figure above, it stated the total coronavirus cases in Malaysia. It shows the cases slightly increase between September to October 2020, the number of cases drastically increase in February 2021. The cases started to increase to peak since Jun and July 2021.

Due to premature deaths, absenteeism, and reduced productivity, the COVID19 pandemic has had a direct impact on income and caused a negative supply shock. Global supply chain disruptions and factory closures have slowed manufacturing production activities. The economic losses caused by the COVID19 pandemic are mainly due to declining demand, which means that no consumers are buying goods and services that are available in the global economy.

The COVID-19 pandemic also has also made all this difficult, especially affecting more than 3.5 million people who work in the tourism industry, in an aviation industry and hotel business. Since the novel coronavirus outbreak, the aviation industry has been the hardest hit in terms of revenue. Global passenger demand for a week is obvious, while Malaysia Airlines has seen a decline in passenger demand to and from China. At the same time, the Malaysian Hotel Association (MAH) estimates that during the Movement Control Order (MCO) period and the sample size is 56,299 hotel industry workers, 2,041 employees were laid off, $9,773(17 \%)$ had to take leave without pay, 5,054 (9\%) pay cuts. 
The pandemic mainly also impacts in the healthcare system. During the pandemic, the unprecedented overwhelming demand for protective equipment, including masks, medical protective clothing, gloves and eye protection, poses a major health risk. The healthcare workers on the front line also at risk of developing distress while managing patients with COVID-19.

Challenges faced in managing COVID-19 pandemic are unprecedented care and logistic challenges, moral distress, huge demand of personal protective equipment (PPE) and the acquisition of medical equipment has been very limited [17]. The challenges identified include financial resources, material challenges, social challenges, education and understanding, cultural challenges, behavioral challenges, religious challenges, capacity challenges and logistical challenges [18]. Health emergency management, health emergency command and decision system, lack of emergency professionals

and insufficient emergency funding also recognized as the challenges faced in managing COVID-19 pandemic [19]. Besides, [20] mentioned three challenges faced such as shortage in personal protective equipment (PPE), ventilators, and potential therapeutic drugs, shortage of masks and limitation on testing and measurement of COVID-19, international data and results from randomized clinical trials of varying sample sizes.

Four core challenges in managing COVID-19 pandemic including the availability of test kits, medical supplies, personal protective equipment (PPE), lack of intensive care unit (ICU) facilities, isolation rooms, and medications, and limited coordination between three levels of government, namely federal, provincial and local levels, and sense of fear among community regarding the pandemic [21]. Three other obstacles in managing this pandemic were financial challenges, demographic challenges and operational challenges [22] . It also highlighted fragmented health and care systems, lack of necessary data and knowledge, inequality in nursing, and informed and interdisciplinary decision-making as the challenges in managing COVID-19 pandemic [23]. The factor such as disruption of limited access to basic services, reorganization of life routine, financial pressure and threat on mental health also an issues faced by the population around the world during the COVID-19 pandemic [13].

Five primary challenges that have been identified by [24] in managing COVID-19 pandemic are health care systems, resource shortage, moral distress, financial viability and vulnerability and disinformation and poor planning. Two significant challenges faced in managing this pandemic were economy recession and education system [25]. Other element such as difficulty to get loan, limitation in wages subsidy program for business and slow down of e-commerce process also the three challenges that faced by industry during this pandemic [26]. Next, [27] stated health care system, economy challenges, industry challenges and educational institutions as the main challenges faced in managing this COVID19 pandemic.

Moral injury and resource shortage as the two core challenges in managing COVID-19 pandemic [28]. Another six challenges faced in managing this pandemic were huge the demand for masks, gloves, hand sanitizer and other basic products, lack of control of waste treatment facilities, lack of technical knowledge and other scientific and economic resources, waste management, panic buying, lack of necessary infrastructure and lack of trained health personnel [29]. Other factors, such as selfimposed or health system restrictions, physical barriers from PPE and "No Visitors" rules, interstate and international travel restrictions and physical distancing also emphasized as the challenges faced in managing pandemic COVID-19 [30]. In addition, another four core challenges is healthcare system, economy ramifications, interrupted supply chain enterprise and education system [25].

Four main challenges in managing COVID-19 pandemic included healthcare system, education system, economic situation and social disruption [31]. On the other hand, four main challenges that have been identified by [32] were economic crises, limited public health capabilities, entrepreneurs and the global crisis and financial challenges. Meanwhile, healthcare system, resource shortage and financial challenges have been recognized as the significant challenges faced in managing COVID-19 pandemic [33]. Likewise, [34] stated two challenges in managing pandemic COVID-19 were health system challenges and patient physician communication.

Table 1 shows the challenges faced in managing COVID-19 pandemic. 
Table 1. Challenges faced in managing COVID-19 pandemic

\begin{tabular}{|c|c|c|c|}
\hline No. & Author & Title & Challenges \\
\hline 1 & [17] & $\begin{array}{l}\text { COVID-19 Pandemic: The } \\
\text { Greatest Challenges in the } \\
\text { History of Critical Care }\end{array}$ & $\begin{array}{l}\text { (1) Unprecedented care and logistic challenge } \\
\text { (2) Moral Distress } \\
\text { (3) Huge demand of personal protective equipment (PPE) } \\
\text { (4) The procurement of medical equipment is very limited }\end{array}$ \\
\hline 2 & [18] & $\begin{array}{l}\text { Potential Challenges in Man- } \\
\text { aging the Coronavirus Pan- } \\
\text { demic in Developing Coun- } \\
\text { tries }\end{array}$ & $\begin{array}{l}\text { (1) Financial Resources } \\
\text { (2) Material Challenges } \\
\text { (3) Social Challenges } \\
\text { (4) Education and Understanding } \\
\text { (5) Cultural Challenges } \\
\text { (6) Behavoural Challenges } \\
\text { (7) Religious Challenges } \\
\text { (8) Capacity Challenges } \\
\text { (9) Logistical Challenges }\end{array}$ \\
\hline 3 & [35] & $\begin{array}{l}\text { Status and Challenges of } \\
\text { Public Health Emergency } \\
\text { Management in China Re- } \\
\text { lated to COVID-19 }\end{array}$ & $\begin{array}{l}\text { (1) Health Emergency Management } \\
\text { (2) Command and Decision System for Health Emergencies } \\
\text { (3) Lack of Emergency Professionals } \\
\text { (4) Insufficient Emergency Funding }\end{array}$ \\
\hline 4 & [20] & $\begin{array}{l}\text { Lessons from Operations } \\
\text { Management to Combat the } \\
\text { COVID-19 Pandemic }\end{array}$ & $\begin{array}{l}\text { (1) Shortage in personal protective equipment (PPE), ventilators } \\
\text { and potential therepeutic drugs. } \\
\text { (2) Shortage of masks } \\
\text { (3) Limitation on COVID-19 testing and measurement, interna- } \\
\text { tional data, and results from randomized clinical trials with differ- } \\
\text { ent sample sizes. }\end{array}$ \\
\hline 5 & [21] & $\begin{array}{l}\text { Public Health Challenges } \\
\text { during the COVID-19 out- } \\
\text { break in Nepal: A Commen- } \\
\text { tary }\end{array}$ & $\begin{array}{l}\text { (1) Availability of testing kits, medical supplies, personal protec- } \\
\text { tive equipment (PPE) } \\
\text { (2) Lack of Intensive Care Unit (ICU) facilities, isolation wards } \\
\text { and medicines } \\
\text { (3) Limited coordination between the three levels of government } \\
\text { i.e. federal, provincial and local levels } \\
\text { (4) Sense of fear among community regarding the pandemic }\end{array}$ \\
\hline 6 & [22] & $\begin{array}{l}\text { The Unique Challenges Fac- } \\
\text { ing Rural Providers in the } \\
\text { COVID-19 Pandemic }\end{array}$ & $\begin{array}{l}\text { (1) Financial Challenges } \\
\text { (2) Demographic Challenges } \\
\text { (3) Operational Challenges }\end{array}$ \\
\hline 7 & [23] & $\begin{array}{l}\text { From Crisis to Coordination: } \\
\text { Challenges and Opportuni- } \\
\text { ties for Integrated Care posed } \\
\text { by the COVID-19 Pandemic }\end{array}$ & $\begin{array}{l}\text { (1) Fragmented health and care systems } \\
\text { (2) Lack of essential data and knowledge } \\
\text { (3) Inequalities in Care } \\
\text { (4) Informed policy making and interdisciplinary decision making }\end{array}$ \\
\hline 8 & [13] & $\begin{array}{l}\text { Challenges and burden of the } \\
\text { Coronavirus } 2019 \text { (COVID- } \\
\text { 19) Pandemic for Child and } \\
\text { Adolescent Mental Health: A } \\
\text { Narrative Review to Highlight } \\
\text { Clinical and Research Needs } \\
\text { in the Acute Phase and Long } \\
\text { Return to Normality }\end{array}$ & $\begin{array}{l}\text { (1) Disruption of limited access to basic services } \\
\text { (2) Re-organization of life routine } \\
\text { (3) Financial Pressure } \\
\text { (4) Threat on mental health }\end{array}$ \\
\hline 9 & [24] & $\begin{array}{l}\text { Ethical Challenges Arising in } \\
\text { the COVID-19 Pandemic: An } \\
\text { Overview from the Associa- } \\
\text { tion of Bioethics Program Di- } \\
\text { rectors (ABPD) Task Force }\end{array}$ & $\begin{array}{l}\text { (1) Health care systems } \\
\text { (2) Resources shortage } \\
\text { (3) Moral Distress } \\
\text { (4) Financial viability and vulnerability } \\
\text { (5) Disinformation and poor planning }\end{array}$ \\
\hline 10 & [25] & $\begin{array}{l}\text { COVID-19 Pandemic: Strin- } \\
\text { gent Measures of Malaysia } \\
\text { and Implications for Other } \\
\text { Countries }\end{array}$ & $\begin{array}{l}\text { (1) Economy recession } \\
\text { (2) Education system }\end{array}$ \\
\hline
\end{tabular}


Table 1. continued...

\begin{tabular}{|c|c|c|c|}
\hline No. & Author & Title & Challenges \\
\hline 11 & [26] & $\begin{array}{l}\text { Struggle of Malaysian SMEs } \\
\text { During the COVID-19 Pan- } \\
\text { demic }\end{array}$ & $\begin{array}{l}\text { (1) Difficulty to get loan } \\
\text { (2) Limitation in wages subsidy program for business } \\
\text { (3) Slow down of e-commerce process }\end{array}$ \\
\hline 12 & [27] & $\begin{array}{l}\text { Challenges Faced by Pan- } \\
\text { demic Covid-19 Crisis: A } \\
\text { Case Study in Saudi Arabia }\end{array}$ & $\begin{array}{l}\text { (1) Health Care System } \\
\text { (2) Economy Challenges } \\
\text { (3) Industry Challenges } \\
\text { (4) Educational Institutions }\end{array}$ \\
\hline 13 & [28] & $\begin{array}{l}\text { Managing mental health } \\
\text { challenges faced by } \\
\text { healthcare workers during } \\
\text { covid-19 pandemic }\end{array}$ & $\begin{array}{l}\text { (1) Moral injury } \\
\text { (2) Resource shortages }\end{array}$ \\
\hline 14 & [29] & $\begin{array}{l}\text { Challenges, opportunities } \\
\text { and innocations for effective } \\
\text { solid waste management } \\
\text { during and post COVID-19 } \\
\text { pandemic }\end{array}$ & $\begin{array}{l}\text { (1) Huge demand for masks, gloves, hand sanitizers and other essential } \\
\text { commodities. } \\
\text { (2) Lack control waste disposal facilities } \\
\text { (3) Lack of technical knowledge and other scientific and economical re- } \\
\text { sources waste management } \\
\text { (4) Panic buying } \\
\text { (5) Lack necessary infrastructure } \\
\text { (6) The lack of trained health workers }\end{array}$ \\
\hline 15 & [30] & $\begin{array}{l}\text { Paedeatric Palliative Care } \\
\text { during the COVID-19 Pan- } \\
\text { demic: A Malaysian Perspec- } \\
\text { tive }\end{array}$ & $\begin{array}{l}\text { (1) Self-imposed or health system restrictions } \\
\text { (2) Physical barriers from PPE and 'No Visitors' rules } \\
\text { (3) Interstate and international travel restrictions } \\
\text { (4) Physical distancing }\end{array}$ \\
\hline 16 & [25] & $\begin{array}{l}\text { COVID-19 pandemic: Strin- } \\
\text { gent measures of Malaysia } \\
\text { and implications for other } \\
\text { countries }\end{array}$ & $\begin{array}{l}\text { (1) Healthcare system } \\
\text { (2) Economy ramifications } \\
\text { (3) Interrupted supply chain enterprise } \\
\text { (4) Education system }\end{array}$ \\
\hline 17 & [31] & $\begin{array}{l}\text { COVID-19 epidemic in Ma- } \\
\text { laysia: Impact of lockdown } \\
\text { on infections dynamics }\end{array}$ & $\begin{array}{l}\text { (1) Healthcare system } \\
\text { (2) Education system } \\
\text { (3) Economic disruption } \\
\text { (4) Social disruption }\end{array}$ \\
\hline 18 & [32] & $\begin{array}{l}\text { The coronavirus (COVID-19) } \\
\text { pandemic: Challenges } \\
\text { among Iranian startups }\end{array}$ & $\begin{array}{l}\text { (1) Economic crises } \\
\text { (2) Limited public health capabilities } \\
\text { (3) Entrepreneurs and the global crisis } \\
\text { (4) Financial challenges }\end{array}$ \\
\hline 19 & [33] & $\begin{array}{l}\text { COVID-19 pandemic: Per- } \\
\text { spectives on an unfolding cri- } \\
\text { sis }\end{array}$ & $\begin{array}{l}\text { (1) Healthcare system } \\
\text { (2) Resources shortages } \\
\text { (3) Financial challenges }\end{array}$ \\
\hline 20 & [34] & $\begin{array}{l}\text { Head and neck virtual medi- } \\
\text { cine in a pandemic era: Les- } \\
\text { sons from COVID-19 }\end{array}$ & $\begin{array}{l}\text { (1) Health system challenges } \\
\text { (2) Patient-physician communication }\end{array}$ \\
\hline
\end{tabular}




\section{METHODS}

The methodology discussed the method of data collection by reviewing on the previous studies on the challenges faced in managing pandemic COVID-19. The source used for this paper is secondary data.

The secondary data is the data collected by a party that has nothing to do with the investigation, but has collected it for any other purpose at a different time in the past. The secondary data is collected from journals, articles, other printed material and so forth. These data were significant as a support to strengthen the decision. The purpose of collecting data through this technique is to determine the challenges faced in managing COVID-19 pandemic in Malaysia.

Table 2: Methodology of Research

\begin{tabular}{|c|l|l|}
\hline No & Research Objective & Method of Research \\
\hline 1 & $\begin{array}{l}\text { To determine the chal- } \\
\text { lenges faced in manag- } \\
\text { ing COVID-19 pan- } \\
\text { demic in Malaysia. }\end{array}$ & Secondary Data \\
\hline
\end{tabular}

\section{RESULTS AND DISCUSSION}

Content analysis is used as data analysis technique in this research. The data is classified into each category of themes. Figure 2 shows the five most significant challenges faced in managing COVID-19 pandemic in Malaysia.

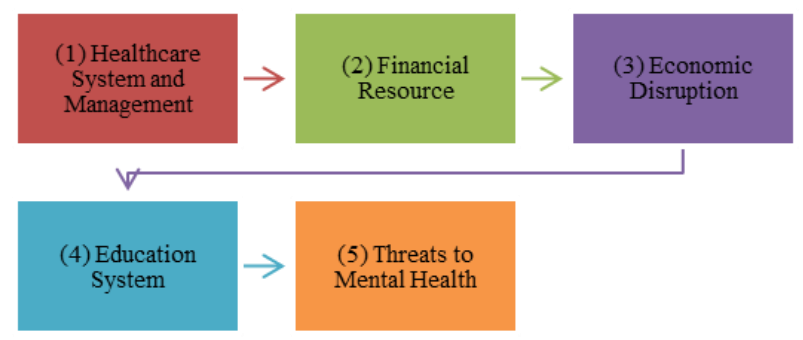

Figure 2. Five Significant Challenges faced in Managing COVID-19 Pandemic.

From the Figure 2, the significant challenges faced in managing COVID-19 pandemic is healthcare system and management. The COVID19 pandemic has developed rapidly in recent months since the outbreak, not only in Malaysia, but health systems in many countries have been implicated and heavily stressed [36]. The next significant is on financial resources. The companies actively assess their risks and vulnerabilities from an operational and financial perspective [37]. In addition, due to premature deaths, absenteeism, and reduced productivity, the COVID19 pandemic has a direct impact on revenues, which has affected the slowdown in manufacturing productivity activities due to economic and manufacturing disruptions the global supply chain [38]. The education system also highlighted as the significant challenges faced in managing COVID-19 pandemic. [39] pointed out that this is because with the spread of school closures and alternative options such as distance education are still out of reach for those who cannot be reached, progress in expanding access to education may be stagnant or reversed. Due to the unprecedented COVID19 pandemic, such as working from home, temporarily unemployed, children who go to school at home, and lack of physical contact with other family members, friends and colleagues, facing new realities and new norms poses threats to mental health. Therefore, fear, worry and stress are normal reactions with uncertainty at this time [40].

\section{CONCLUSION}

In a conclusion, the researcher had analysed the findings of the study which had achieving the research objective of the study. Throughout the results, the researcher able to identify the significant challenges faced in managing pandemic COVID-19 in Malaysia. As a result, the most significant challenges identified in managing COVID-19 pandemic in Malaysia are Financial Resources, Health Care System, Social Challenges, Education System, and Threats to Mental Health.

\section{ACKNOWLEDGMENT}

This research work is supported by the KANZU Knowledge Consultant, under Ibn Battuta grant, VOT (M014): Challenges Faced in Managing COVID-19 Pandemic, Case Study: Malaysia. Also, I would like to thank UTHM for giving me an opportunity to be part of this grant.

\section{REFERENCES}

[1] L. R. Mbbs, L. B. S. M. D, and M. S. Neurosurgery, "Coronavirus Disease Coronavirus Disease ( COVID-19 ) Spreads,” Who, vol. 75, no. 2, pp. 9597, 2020.

[2] "Covid-19 weekly round-up_ Only 85 active cases left in Malaysia The Edge Markets."

[3] A. Elengoe, "CŌVID-19 Outbreak in Malaysia," Osong Public Health and Research Perspectives, vol. 11, no. 3. pp. 93-100, 2020. doi: 10.24171/j.phrp.2020.11.3.08.

[4] Vlaanderen, "CORONA VIRUS - The situation in Malaysia | Flanders Trade," no. June. pp. 1-17, 2020.

[5] A. A.A., H. M.R., S. T.J., A. S.H., and M. E., "Public knowledge, attitudes and practices towards 
COVID-19: A cross-sectional study in Malaysia," PLoS ONE, vol. 15, no. 5. 2020.

[6] A. U. M. Shah et al., "COVID-19 outbreak in Malaysia: Actions taken by the Malaysian government," Int. J. Infect. Dis., vol. 97, pp. 108-116, 2020, doi: 10.1016/j.ijid.2020.05.093.

[7] Z. I. Azhar, X. W. Chen, M. Mohamad, M. S. Ahmad Saman, M. R. Isa, and N. Ismail, "COVID-19 Review: An Epidemiological Perspective and Malaysian Scenario in Handling the Pandemic (January May 2020)," J. Clin. Health Sci., vol. 5, no. 1, p. 26, 2020, doi: 10.24191/jchs.v5i1.9002.

[8] N. F. C. Mat, H. A. Edinur, M. K. A. A. Razab, and S. Safuan, "A single mass gathering resulted in massive transmission of COVID-19 infections in Malaysia with further international spread," $J$. Travel Med., vol. 27, no. 3, pp. 1-4, 2020, doi: $10.1093 / \mathrm{jtm} / \mathrm{taa} 059$.

[9] H. Jaafar and A. Azzeri, "Winning the war against COVID-19 in Malaysia: An achievable goal?," Malays. J. Public Health Med., vol. 20, no. 1, pp. 148149, 2020, doi: 10.37268/mjphm/vol.20/no.1/art.493.

[10] "Covid-19: Travel in the time of coronavirus and movement control order | The Star Online."

[11] DG of Health Malaysia, "The Malaysian Response to COVID-19: Building Preparedness for 'Surge Capacity', Testing Efficiency, and Containment From the Desk of the Director-General of Health Malaysia," Kpkesihatan. 2020.

[12] K. Ho and D. Tang, "Movement control as an effective measure against Covid-19 spread in Malaysia : an overview," pp. 17-20, 2020.

[13] J. M. Fegert, B. Vitiello, P. L. Plener, and V. Clemens, "Challenges and burden of the Coronavirus 2019 (COVID-19) pandemic for child and adolescent mental health: A narrative review to highlight clinical and research needs in the acute phase and the long return to normality," Child Adolesc. Psychiatry Ment. Health, vol. 14, no. 1, pp. 1-11, 2020, doi: 10.1186/s13034-020-00329-3.

[14] S. Sundarasen et al., "Psychological impact of covid-19 and lockdown among university students in malaysia: Implications and policy recommendations," Int. J. Environ. Res. Public. Health, vol. 17, no. 17, pp. 1-13, 2020, doi: 10.3390/ijerph17176206.

[15] M. Sengupta, A. Roy, A. Ganguly, K. Baishya, S. Chakrabarti, and I. Mukhopadhyay, "Challenges Encountered by Healthcare Providers in COVID-19 Times: An Exploratory Study," J. Health Manag., vol. 23, no. 2, pp. 339-356, 2021, doi: $10.1177 / 09720634211011695$.
[16] Coronavirus Update (Live)_41,169,789 Cases and 1,131,329 Deaths from COVID-19 Virus Pandemic - Worldometer.

[17] R. Ferrer, "COVID-19 Pandemic: the greatest challenge in the history of critical care," Med. Intensiva, vol. 44, no. 6, pp. 323-324, 2020, doi: 10.1016/j.medin.2020.04.002.

[18] S. Bere, "Potential Challenges in Managing the Corona Virus Pandemic in Developing Countries," no. April, 2020.

[19] Y. Cao, J. Shan, Z. Gong, J. Kuang, and Y. Gao, "Status and Challenges of Public Health Emergency Management in China Related to COVID19," Front. Public Health, vol. 8, no. May, pp. 1-6, 2020, doi: 10.3389/fpubh.2020.00250.

[20] J. R. Patrinley, S. T. Berkowitz, D. Zakria, D. J. Totten, M. Kurtulus, and B. C. Drolet, "Lessons from Operations Management to Combat the COVID-19 Pandemic," J. Med. Syst., vol. 44, no. 7, 2020, doi: 10.1007/s10916-020-01595-6.

[21] S. Sharma and J. Bhatta, "Public health challenges during the COVID-19 outbreak in Nepal: a commentary," J. Health Res., vol. 34, no. 4, pp. 373 376, 2020, doi: 10.1108/JHR-05-2020-0124.

[22] J. E. Segel, H. I. Ross, J. L. Edwards, K. A. Braun, and L. A. Davis, "The Unique Challenges Facing Rural Providers in the COVID-19 Pandemic," Popul. Health Manag., vol. 00, no. 00, pp. 1-3, 2020, doi: 10.1089/pop.2020.0151.

[23] K. Viktoria Stein, N. Goodwin, and R. Miller, "From crisis to coordination: Challenges and opportunities for integrated care posed by the COVID-19 pandemic," Int. J. Integr. Care, vol. 20, no. 3, pp. 1-3, 2020, doi: 10.5334/ijic.5595.

[24] A. L. McGuire et al., "Ethical Challenges Arising in the COVID-19 Pandemic: An Overview from the Association of Bioethics Program Directors (ABPD) Task Force," Am. J. Bioeth., vol. 20, no. 7, pp. 15-27, 2020, doi: 10.1080/15265161.2020.1764138.

[25] S. Umair, U. Waqas, and M. Faheem, "COVID-19 pandemic: Stringent measures of Malaysia and implications for other countries," Postgrad. Med. J., pp. 2-4, 2020, doi: 10.1136/postgradmedj-2020138079.

[26] P. Brief, "Struggle of Malaysian SMEs During the COVID-19 Pandemic Findings from Webinar: SMEs Beyond the MCO - Observations and Recommendations," no. May, 2020.

[27] M. Parveen, "Challenges Faced by Pandemic Covid 19 Crisis: A Case Study in Saudi Arabia," Challenge, vol. 0, no. 0, pp. 1-16, 2020, doi: 10.1080/05775132.2020.1822659. 
[28] N. Greenberg, M. Docherty, S. Gnanapragasam, and S. Wessely, "Managing mental health challenges faced by healthcare workers during covid-19 pandemic," The BMJ, vol. 368, no. March, pp. 1-4, 2020, doi: 10.1136/bmj.m1211.

[29] H. B. Sharma et al., "Challenges, opportunities, and innovations for effective solid waste management during and post COVID-19 pandemic," Resour. Conserv. Recycl., vol. 162, no. May, p. 105052, 2020, doi: 10.1016/j.resconrec.2020.105052.

[30] L. A. Chong, E. J. Khoo, A. A. Kamar, and H. S. Tan, "Paediatric Palliative Care during the COVID19 Pandemic: A Malaysian Perspective," Asian Bioeth. Rev., 2020, doi: 10.1007/s41649-020-001422.

[31] N. Salim et al., "COVID-19 epidemic in Malaysia : Impact of lockdown on infection dynamics," no. May, 2020.

[32] A. Salamzadeh and L. P. Dana, "The coronavirus (COVID-19) pandemic: challenges among Iranian startups," J. Small Bus. Entrep., vol. 0, no. 0, pp. 124, 2020, doi: 10.1080/08276331.2020.1821158.

[33] A. Spinelli and G. Pellino, "COVID-19 pandemic: perspectives on an unfolding crisis," Br. J. Surg., vol. 107, no. 7, pp. 785-787, 2020, doi: 10.1002/bjs.11627.

[34] A. Prasad, R. M. Carey, and K. Rajasekaran, "Head and neck virtual medicine in a pandemic era: Lessons from COVID-19," Head Neck, vol. 42, no. 6, pp. 1308-1309, 2020, doi: 10.1002/hed.26174.

[35] Y. Cao, J. Shan, Z. Gong, J. Kuang, and Y. Gao, "Status and Challenges of Public Health Emergency Management in China Related to COVID19," Frontiers in Public Health, vol. 8. 2020. doi: 10.3389/fpubh.2020.00250.

[36] N. Md Hamzah, M. M. Yu, and K. F. See, "Assessing the efficiency of Malaysia health system in COVID-19 prevention and treatment response," Health Care Manag. Sci., no. January 2020, pp. 273-285, 2021, doi: 10.1007/s10729-020-09539-9.

[37] Deloitte, "Rapid respond \& recover approach Actions for crisis mitigation can be divided into four specific taskforces that are mandated and coordinated by," no. April, 2020.

[38] A. Pak, O. A. Adegboye, A. I. Adekunle, K. M. Rahman, E. S. McBryde, and D. P. Eisen, "Economic Consequences of the COVID-19 Outbreak: the Need for Epidemic Preparedness," Front. Public
Health, vol. 8, no. May, pp. 1-4, 2020, doi: 10.3389/fpubh.2020.00241.

[39] T. Azzi-Huck, K., \& Shmis, "Managing the impact of COVID-19 on education systems around the world: How countries are preparing, coping, and planning for recovery.," World Bank Blogs, p. 18, 2020.

[40] WHO, "Mental health \& COVID-19," World Health Organ., pp. 1-5, 2021. 